\title{
Ethics as First Philosophy
}

\author{
Michael D. Dahnke
}

Temple University

The phrase "ethics as first philosophy" is most identified with Emmanuel Levinas. It is the idea, put simply, that what has been traditionally looked to as first philosophy, usually epistemology or metaphysics, is not first in any sense at all. Rather, all such positions are dependent on a precedent ethics. Thus, ethics becomes first philosophy. In my investigation of the concept here, I intend to place it in a broader context of Continental philosophy, identifying the threads of Continental thought that inform the concept, both within and outside the limits of the phenomenological, and primarily through the lens of the influential predecessors Nietzsche and Heidegger. In this way I hope to provide a deeper understanding of the concept and possibly a broader defense of its validity.

First Philosophy:

The Concept, The Tradition

The logic of a first philosophy suggests a starting point, a definite beginning, a "getting to the bottom of things, seeing things whole and clear"(Page xii), a secure foundation. Foundation, yes, I like that. Philosophy abounds with building metaphors: foundations, ladders, bricks, scaffolding, constructionism, deconstructionism, boards, planks, nails. . . Such building metaphors allow philosophers to explicate a world or system that is made up of parts that are interdependent, job-specific and hierarchically posed. That is, certain parts are conceived as more important than others for they maintain the structure of the building. While other, more trivial parts, provide only ancillary support or even mere decoration. Without the "foundation" of the more important parts, the more trivial parts would have no purpose and would indeed fall in on themselves. 
The logic of first philosophy employs this manner of metaphor to elucidate a hierarchical ontology in which a foundation is necessary to support all derivative thought (i.e. ancillary support and decoration). Traditionally, this foundation has been established in the realm of metaphysics or epistemology, where clear logic and fixed, static reality converge, allowing the perspicacious philosopher to see things "whole and clear." Metaphysics, the establishment of fixed, unchanging stuff, substance, ousia, ideas, etc., provides a concrete, unshifting basis on which to build further reality. Epistemology, the establishment of cognitive categories through which the structure of the world is taken in and understood, provides the window (without or potentially without refraction) through which basic foundational knowledge is attained and maintained. Once these are established, other forms of knowledge, forms of philosophy, can be sought and justified. These are the parts of the building that provide ancillary support and decoration: political philosophy, ethics, aesthetics. Traditionally, these areas of philosophy have been somewhat marginalized, seen as less real, less important, more trivial. Sometimes they are conceived as utterly distinct from those most real areas of philosophy and sometimes utterly dependent on them for arguments and justification and ultimately for their very being.

Descartes is well known for his search for a first philosophy, one that would dispel all doubt and concretize certain knowledge. Having doubted the entire world out of existence, he then established the one piece of knowledge that could not be doubted away: the cogito. From there with the help of his version of the ontological argument, he re-established the existence of God and from there repopulated the world. Not until the epistemological basis of one bit of certain knowledge and the metaphysical foundation of the world are established can life go on. Not until then can we know if anything we do has any meaning. Not until then can we be sure any decision we make is correct. Not until then can we be sure what direction to take in any aspect of life. Because not until then can we know for sure what's real and what's not. Not until then can we know that our perception is clear.

Plato too is known for his search for knowledge that will act as support for further, derivative knowledge. Plato's inspiration for 
this search was a response to the relativism of the sophists. He delved into metaphysics and epistemology in order to argue the objective moral claims of Socrates. In this way, for Plato, metaphysics and epistemology precede ethics, provide support and justification for ethical claims, turn superficial values into facts. Without good reason and the support of knowable reality behind it, ethics is blind and confused.

Kant also worked hard to transpose values into facts. Both The Metaphysics of Morals and The Critique of Practical Reason establish an ethics based on rational arguments that follow from his studies in metaphysics and epistemology. For Kant, like Plato, ethics could not stand alone. Without the proper foundation it could only shift, slip and slide until it fell in on itself.

This quest for certain knowledge has become a longstanding tradition or even obligation in Western philosophy. However, the late modern era (or "postmodern" era) has time and again questioned the efficacy of such a quest, problematized the assumption of the clear reception of such knowledge, genealogically explored the motivation behind such a quest and critiqued the presumption of an obligation for such a quest. In the U.S. such attacks can be found in Jamesian pragmatism, Deweyan instrumentalism and Rortyan irony. In Europe similar attacks have been made by Nietzschean perspectivism, late Wittgensteinian ordinary language theory, Heideggerian hermeneutics, Lyotard's postmodernism, Derridean deconstructionism and Foucaultian rapports de pouvoir. This is not to say that the quest for objective knowledge has completely vanished from the philosophical landscape. This quest is still alive for many Anglo-American philosophers and Continental philosophers as well. And even for some of the critics alluded to above (as well as the countless others who flank them) objective knowledge is often a concern as they fight the diametric "demon" of relativism. For even some of the most radical philosophers today relativism will not be permitted or admitted. That is, either they will not allow themselves to head in that direction or they will not admit the fact, obvious to everyone else, that the direction their thought points, inevitably and ineluctably toward, is relativism. The problem is that relativism brings with it the risk of the loss of any kind of assurance, including (or perhaps, espe- 
cially) normative assurance. And without normativity the ethicopolitical stance of political and politically active philosophers like Dewey, Wittgenstein, Rorty, Derrida and Foucault cannot be defended. And historical horrors such as the Holocaust and African slave trade cannot be reviled and may well occur again. And certainly the problem of Heidegger brings this concern to life.

\section{Conceptual Adjustment:}

First Philosophy, Ethics

The traditional definitions of both first philosophy and ethics will not work here. To apply to such a project, a reasonable adjustment needs to be made for each. Certainly, with the loss of foundational knowledge already admitted (and accepted, affirmed, celebrated), first philosophy can no longer mean "getting to the bottom of things, seeing things whole and clear" (Page xii). If we return to the building metaphor and extend it a bit, we realize that any foundation itself must be built. A foundation is not merely a found piece of firm ground. It is dug in, laid, and built up. "Without a secure foundation a building will collapse" is a true statement. But "Without a well-built foundation a building will collapse" is more accurate. Before construction the placement of a foundation has to be chosen (for geological, geographical and demographic reasons). The forces that the planned building will exert must be calculated. And the foundation must be dug into that chosen ground and adequate building materials (bricks, cinder blocks, cement-which are the actual foundation) must be laid according to the calculations of exerted force. Applying this analogy to foundational knowledge or first philosophy, then, a so-called first philosophy must be chosen for identifiable (even mundane) reasons and enforced to withstand expected stress. There is a certain sense in which it is obviously very contingent. Another building site could have been chosen. The expected stressors could have been different, thereby changing the manner of laying the foundation. So, though it might sound contrary, any notion of "first philosophy" I use must include a sense of contingency. And the foundation of foundational knowledge is secure but not so secure that it could never be torn up. This fact, however, both in construction 
and in philosophy, does not mean that the building is useless. It can serve a function-any number of functions. But this fact does recognize that the building does serve a number of specific, intended functions. That is, there are specific purposes precedent to the laying of a foundation. In this way first philosophy is understood as not universalizable and non-contingent but as simply precedent to other, further studies and directive toward certain, intended goals.

The use of the term ethics I wish to suggest here is not a simple matter at all. Traditional definitions concern an analysis of good and bad, the search for the good life. And I do not wish to completely abrogate these approaches. But I want to expand the conception of ethics in two directions: 1) to include those trivial aspects of life and behavior not usually recognized as important enough to be considered ethical matters. Traditionally the name ethics has been reserved for the grand questions of life and conduct: sexuality, death (murder, suicide, abortion, self-defense), justice, politics, the general and ultimate direction of one's life. But I wish to include (indeed, emphasize) all manner of activity and every trivial decision. Accordingly, the way one dresses is implicated in ethics. The music one listens to is an ethical concern. So is the car one drives. So is where one eats breakfast: whether at the local, trendy cafe/bookstore, an old-fashioned coffee shop, McDonald's, one's own kitchen, or even sitting in bed eating dry Froot Loops out of the box while watching McMillan and Wife reruns. 2) The other direction is the opposite direction. Ethics expands to include not only the so-called "grand questions" of life but what lies behind those "grand questions": the reasoning process upon which any answer might be based, the motivation for making those questions "grand questions," etc. For a more concrete (though admittedly contingent and revisable) definition, I propose: an amorphous set of often undifferentiated beliefs, thoughts, practices and knowledge that order both individual and collective life, and which is both inherited through enculturation and causa sui in the sense of being transformed through practice. This definition first establishes that ethics is not a fixed entity by including amorphousness as one of its qualities. It also breaks down the cognitive/noncognitive distinction by admitting that the distinction be- 
tween beliefs, thoughts, practices and knowledge can often be vague and even undifferentiated, or at least difficult to differentiate. The definition includes both personal and public conduct. Further, the definition admits a cultural/historical perspective in being inherited as well as a creative aspect in admitting that change occurs through the very practice of ethics. Also, the definition is consistent with and probably influenced by Foucault's understanding of Greek ethics: "a way of being and of behavior...a mode of being of the subject, along with a certain way of acting, a way visible to others. A person's ethos was evident in his clothing, appearance, gait, in the calm with which he responded to every event, and so on" (Foucault 286).

\section{Nietzsche}

Nietzsche's contributions to the understanding of this issue lie primarily in his genealogy, his Will to Power, his perspectivism, and his overriding sense and valuation of creativity. Nietzsche's genealogy taught us that even the most seemingly natural of practices has a contingent history. Morals, and all the aspects of morals (guilt, compassion, good, evil) are understood then not as natural entities but as historical phenomena. In this way he deflates the English moralists, whose "heaving breasts seem to them the bellows of godliness..." (Nietzsche, The Will to Power 232). Nietzsche's Will to Power strips ethical thought of all extravagance. Sentimental prejudices are tossed aside. Overwrought proofs are destroyed. What is left is the simple dichotomy of life affirmation/life denial. Nietzsche's perspectivism allows a complete explanation of genealogical study. The multiple directions that ideas and beliefs take are explained through the multiplicity of perspectives. Nietzsche powerfully explains, "There is only a perspective of seeing, only a perspective of 'knowing'...to eliminate the will altogether, to suspend each and every affect, supposing we were capable of this-what would that mean but to castrate the intellect" (Nietzsche, On the Genealogy of Morals 119). So perspectival knowledge is not only admitted but required. The admittance of perspective legitimizes different ways of being, thinking, believing rather than holding the Parmenidean charge that only 
one way can be the way that "is." Finally, the Nietzschean sense of creativity reinforces the affirmation of life, refuses the impotence of ascesis, and, while assured by perspectivism, reflexively increases the multiplicity of perspectives.

Nietzsche is the great destroyer, the great leveller. He wields his hammer with equal destructive force against all foes, all institutions, all philosophies, all moralities, all metaphysics. Many philosophers (every worthwhile philosopher to some degree) have destroyed, critiqued, destabilized that which came before them. But none before or since have done so with the vigor, the relish, the relentless, unforgiving aggression of Nietzsche. Never before or since has such an attack been leveled against the prejudices, the status quo, the unquestioned, entrenched, static beliefs and presumptions of Western thought. Nietzsche pulled philosophy from the clouds of esoteric and transcendental intellect down to the real world of life and filth and raw power, of bodies and urges and low beginnings: "Behind all logic and its seeming sovereignty of movement, too, there stand valuations, or, more clearly, physiological demands for the preservation of a certain type of life" (Nietzsche, Beyond Good and Evil 11). This aspect of Nietzsche's thought establishes the reality and potential moral evaluation of the naked, immediate world which surrounds us: a world of ubiquitous conflict, filthy, animalistic bodies and messy, overflowing discharge. What I am suggesting here is an important ontological point. Just as Plato established the reality of forms-as perfect, eternal, unchanging - and worked downward from there ontologically, divesting the physical world of significant reality, Nietzsche begins ontologically with that which is lowly (the hair, mud, and dirt that Socrates curled his pug-nose at), investing primary reality there and demonstrating that all, supposedly higher, forms of being, knowledge, reality are somehow (usually with a marked sense of artificiality) built upon these. And since Plato the relationship between ethics and ontology has been, if not fully understood, at least apparent. That which is real (unchanging, eternal, "perfect"), that which is ontologically prime and prior, is ethically prime. So, too, with Nietzsche the dust into which universals, substances and essences are pounded is blown away like so much insubstantial powder. 
What follows is that the motivation behind any thought or logic and the direction it takes is not some high-minded pursuit of that which is unbiased, objective, true, but something very biased, subjective (or perspectival) and instinctive: "the preservation of a certain type of life." Again, here we are reduced to the lowly constituents of being, the mere perpetuation of life, which includes all that is agonistic, bloody, selfish and thrusting.

Not only does "the preservation of a certain type of life" include all that is bloody and selfish, but it also suggests a very specific, even narrow, direction and perspective for thought. This is a perspective that, of course, works toward itself, its own survival. It is selfish and autonomous in the true meaning of the word: selflaw-giving. To do otherwise would mean death, extinction. And life would cancel itself out. So any logic is an attempt to perpetuate oneself. To think otherwise would be self-defeating. To think other/wise would be self-defeating. In this sense the other becomes the enemy as the self struggles for its own survival. But this is to a certain extent a necessary process. Only three possible perspectives present themselves: the perspective of the self, the other, and God or eternity - that is, the perspective of all perspectives or the Perspective without perspective. The perspective of the other presents an inherent danger. And the perspective of eternity is really no perspective. It is without will, without time, without life. What Nietzsche affirms and celebrates is our own limited perspective, for it is its very limits that gives it meaning. "There is only a perspective of seeing, only a perspective of 'knowing'.. . But to eliminate the will altogether, to suspend each and every affect, supposing we were capable of this-what would that mean but to castrate the intellect?"(Nietzsche, On the Genealogy of Morals 119). "Castrate the intellect," a very powerful, telling metaphor that brings home the lowly beginnings and selfish, carnal motivations of the highest thoughts.

This perspectivism of Nietzsche's leads to a questioning and possible understanding of the Other. Note again the quote from Beyond Good and Evil I cited earlier. The whole paragraph reads:

Behind all logic and its seeming sovereignty of movement, too, there stand valuations or, more 
clearly, physiological demands for a certain type of life. For example, that the definite should be worth more than the indefinite, and mere appearance worth less than "truth"-such estimates might be, in spite of their regulative importance for $u s$, nevertheless mere foreground estimates, a certain kind of niaiserie which may be necessary for the preservation of just such beings as we are. Supposing, that is, that not just man is the "measure of things" (Nietzsche, Beyond Good and Evil 11).

The reference to Protagoras at the end presents what appears to be a surprising attack on relativism, considering the relativistic slant of the rest of the paragraph. But it is a very telling and important remark. It is not at heart any kind of critique of relativism or support for objectivism. What Nietzsche is pointing to by questioning man as "the measure of things" is man as a static limit. "Man" for Nietzsche is a decentered focus. Kant set "man" up as the somewhat passive lens through which knowledge of the world is gained/ constructed. As such "man" for Kant stands still. But for Nietzsche man is not the "measure of things" for I) man himself is constructed knowledge and 2) man can always be more than he is. Man is decentered. The suggestion is that there is something beyond man, that there are things of no importance for our preservation that we neither value, recognize nor even see, but that exist nonetheless. Of course the existence of that which is outside our purview is an old and even clichéd problem in philosophy. Aristotle ridiculed Plato's redoubling of this world. Berkeley maintained the existence of that which is not perceived by naming God as the great perceiver. But in this case, rather than a concern over physical objects blinking in and out of existence, what we have is an expression of perspectivism and the relation of the other. The other always has a different perspective and always constructs reality differently.

By capitalizing on the sexist language both Nietzsche and I have been using up till now, we can develop this line of thought in a concrete manner by interpreting the other as woman, and by un- 
derstanding a different perspective, a different reality surrounding women. Recognizing this different perspective, this different "measure of things," we understand the status of even our most important world-forming ideas as "mere foreground estimates." This recognition of the other does two things. First, it decenters man as the single lens through which reality is perceived and understood. Second, it points out the contingency of the perspective of man and the possibility to change (expand, decrease, skew) that perspective so that man is not "the measure of things" and the possibilities of being open up.

Of course this post-feminist interpretation of Nietzsche might be considered ex post facto or anachronistic, but I think it clarifies, from a contemporary viewpoint, what Nietzsche was getting at: the contingency, motivations, and limited perspective of any valuation. And, as we saw earlier, this limited perspective is necessary in order to give the intellect a direction. Or, to take the castration metaphor further, this limited perspective is necessary to give the intellect power and vitality and virility.

But also in evaluation of the appropriateness of the criticofeminist interpretation, another important, highly complex issue arises. When we speak of the "us" that is facing the other, whom exactly are we speaking of? Are we speaking of "man," "humanity," "white men," "middle-aged heterosexual white men"? Could we perhaps even be speaking of an individual? When this question arises, the issue then takes on a more traditional, familiar face: egoism. Of course egoism (psychological, ethical) is traditionally understood as attributable to individuals. It is the primary concern for oneself (as subject and/or object) in all matters of choice. It is a position which has had its share of supporters but many, many critics as well. But if we try to understand Nietzsche's position in terms of egoism, we breakdown the barrier that limits the attribution of egoism to the individual and resolve or nullify many of the traditional critiques of egoism. Hence, the "egoistic subject" becomes an open question attributable to any indefinite group that can be shown to have its own selfish interests. And this group chooses for itself (for its own survival) often in competition with other groups, often in competition with other groups whose members may include some of the first group's members. In this way 
individual members acquire fractured loyalties which may or may not be problematic, depending on the nature of the various memberships, the needs of the individual, and the nature of the groups themselves. Conflict and competition further arise when different groups override one another when a hierarchical order ensues.

What we have here is a kaleidoscope of competing perspectives. The perspectives that win (any victory is only ever temporary) take on the status of "faith," the unquestioned justification. And from this faith science acquires "a direction, a limit, a method, a right to exist" (Nietzsche, On the Genealogy of Morals 152). The language of Nietzsche here is very important. It recalls the position that cognitive perspective is not only a fact but a necessary fact. The science through which we view, understand and analyze our world is justified (has "a right to exist") not simply because it is true (which would here be only a first-level, superficial justification) but because the battle of perspectives (which is really a battle of wills to life) has established not only the need for a perspective cum faith cum science but a need for that particular perspective-faith-science in order to answer the "physiological demands of a certain type of life." This right, then, based on what exists in the world of facticity dissolves the is/ought distinction. This right, this justification is not (and need not be) based on objective, ahistorical criteria but on "physiological demands," on flesh. Decadent though it may be, it is a real enough, stable enough, objective enough standard to justify science, metaphysics, etc. Flesh incarnate, which philosophy has so long abjured, is what determines such directions and motivations. Flesh incarnate is what makes the face of the other important, a force to be dealt with and the beginning of understanding.

\section{Heidegger}

In order to further our understanding of "ethics" here, consider the etymological reading which Heidegger brings to the word as that "which ponders the abode of man" (Heidegger 235). The metaphor of ethics as an abode, a house, a dwelling, a place for living, I find very instructive. It provides a spatial sensibility that leads to the connection between ethics and ontology that Heidegger 
sought to explore and that I do as well. For I believe that it is with this connection that we will understand what sort of obligations ethics inculcates and why. However, what I find puzzling, mysterious and ultimately of no use from my point of view is this idea of "Being" with a capital " $B$ " and originary ethics, nor do I have any idea what an originary ethics would consist of. Origins seem too distant to me. I can only relate to being with a lower-case "b." This "being" is (or can be) immanent, full, rich and factical. I personally feel no primordial connection to Being, nor do I have any confidence in the possibility of discovering an originary ethics. As Jack Caputo so pithily expressed it: "Though I wait daily by my phone, though I keep my ear close to the ground, I cannot, for the life of me, hear the call of Being" (Caputo 12). But the ontoethical sense that ethos/abode suggests, I find very instructive.

In Heidegger's "Letter on Humanism" he etymologically studies the word ethics, finding the Greek root, ethos, of particular interest and much fuller and more original than the narrow field of "ethics" introduced by Plato and developed by Aristotle. The more interesting term ethos, says Heidegger, "means abode, dwelling place." And Heidegger continues, "The word names the open region in which man dwells. The open region of his abode allows what pertains to man's essence, and what in thus arriving resides in nearness to him, to appear. The abode of man contains and preserves the advent to what belongs to man in his essence" (Heidegger 233). This etymological analysis, I think is tremendously important to understanding what ethics means and retrieving that meaning from the parochial clutches of moral philosophers who, even one hundred years after Nietzsche, are hung up with a determinate sense of right and wrong, good and evil. However, I find myself at odds with Heidegger's further development of this notion of abode as "originary ethics" which will reconnect man with Being, the primordial element of man. First of all, I know not what "true Being" would be and know not how one would study or establish such a thing. Secondly, the decadent character of flesh makes any putative knowledge of origin of dubious value. 
Abode, nonetheless, is a fabulously instructive metaphor, and I do follow Heidegger in this respect to a point. And where I break from Heidegger I find Levinas' interpretation of dwelling much more on track. In Levinas the dwelling, the abode loses that search for what is original and true. For Levinas, man has not lost touch with Being, but his being is defined by that ethos or abode which centers, delimits and nurtures his ontic, cognitive and epistemological life: "The privileged role of the home does not consist in being the end of human activity but in being its condition, and in this sense its commencement" (Levinas 152). There is a sense of the abode being an origin in Levinas as well but not a final origin that points to true Being, merely the condition of being as it's understood both as within any contemporary context and as defined less by metaphysical existence than by activity.

What in Heidegger that is retained is this notion of what pertains to man's essence residing near to him and the abode containing and preserving "what belongs to man in his essence." The verb "belongs" is very important here, for possession of one's being, one's world is the very definition of having a being, a world: "Possession masters, suspends, postpones the unforeseeable future of the element-its independence, its being" (Levinas 158). "Possession posits the product of labor as what remains permanent in time, a substance" (Levinas 160). An odd parallel exists between this metaphorical use of labor and possession and Locke's literal use as the apples of the orchard becomes one's own (one's possessions) once one's labor is added to them through the picking of the fruit. Just so, the labor of constructing one's home, bringing objects within it, makes the world one's possession. So there is constituted both a within and a without, the without being that measure which Nietzsche suggests, is beyond "man as the measure."

What is within is the world that is one's life, one's onticity (ontology?), one's being: "The primordial function of the home does not consist in orienting being by the architecture of the building and in discovering a site, but in breaking the plenum of the element, in opening in it the utopia in which the ' $I$ ' recollects itself 
in dwelling the latent birth of the world is produced" (Levinas 156). This is a world (a home) of things and beings all possessed through taking and comprehending (prend et comprend). What is in the home, "near the body is possessed, is intentionality of concretization" (Levinas 153). What is outside the home is the alterity of a different, world, a different home, the Other. What is other is indifferent, malevolent or simply unknowable to one's home. Thus what sustains and perpetuates one and one's home is valued, the "physiological demands for the preservation of a certain type of life." Or, in the words of Levinas echoing Nietzsche: "What is necessary to my existence in order to subsist interests my existence" (Levinas 164). What is outside, if indifferent or unknowable is ignored, if malevolent (or perceived as malevolent), is feared, hated, attacked. For it is not outside of one's world that the relationship with the Other is produced but within that world and in the very act of putting that world in question. The mere valuation of truth over falsity, the definite over the indefinite, stasis over change, objective knowledge over subjective knowledge reflect the valuations necessary for creatures such as us and thereby are justified on those somewhat contingent grounds. Further, it is valuations such as these that construct our home, our world, our ontology, and, foremost, our ethics. The manner in which we value what sustains us and how we construct our relationships to the Other forms an ethical field that is incarnated in the world that is our home. "Morality is not added to the preoccupations of the I, so as to order them or have them judged; it calls in question, and puts at a distance from itself, the I itself' (Levinas 172). And, by putting the $I$ in question, the $I$ is given definition, a justification, a home and the direction, motivation and justification for all further thought and belief.

But again we need to question this separation between the I (we?) and the Other. Where does this separation occur and how is it transcended? A simple, clear-cut distinction between I and Other would be difficult to defend, dangerous to maintain and ultimately solipsistic.

What transcends these barriers, according to Levinas, is language: "it is contact across a distance, relation with the non-touchable, across a void" (Levinas 172). Through generalization and 
universalization language speaks the world to the Other, thereby instituting a common world and transcending the void between I and Other. In this way the barrier of that void is dissolved, if only partially, and the Other is no longer other, but a common "we." In this way any Other is potentially part of the world of "I." The barriers between I and Other are porous, non-absolute and subject to change. It follows from this that one's world, one's dwelling, one's ontology, one's ethics is also non-absolute and subject to change. And it is this primordial recognition of the Other that is the first ethical event, and that provides the contingent background and forward direction and motivation for further thought and practice which is first philosophy.

\section{Works Cited}

Caputo, John D. Against Ethics: Contributions to a Poetics of Obligation with Constant Reference to Deconstruction. Bloomington, Indiana: Indiana University Press, 1993.

Foucault, Michel. "The Ethics of the Concern for Self as a Practice of Freedom." Ethics, Subjectivity and Truth, Essential Works of Foucault, 1954-1984, Volume I, edited by Paul Rabinow, translated by Robert Hurley, et. al. New York: The New Press, 1997.

Heidegger, Martin. "Letter on Humanism." Martin Heidegger:

Basic Writings, edited and translated by David Farrell Krell.

New York, Hagerstown, San Francisco, London: Harper \& Row, 1977.

Levinas, Emmanuel. Totality and Infinity: an Essay on Evteriority.

Translated by Alphonso Lingis. Pittsburgh: Duquesne University Press, 1969.

Nietzsche, Friedrich. On the Genealogy of Morals. Translated by Walter Kaufmann and R.J. Hollingdale. New York: Vintage Books, 1967.

Nietzsche, Friedrich. The Will to Power. Edited by Walter Kaufman, translated by Walter Kaufmann and R.J. Hollingdale. New York: Vintage Books, 1967.

Page, Carl. Philosophical Historicism and the Betrayal of First Philosophy. University Park, Pennsylvania: Pennsylvania State University Press, 1995. 
Theodor Adorno. Critical Models: Catchwords and Interventions. Edited by Henry W. Pickford. (New York: Columbia University Press, 1998).

\section{Andrew Knighton \\ University of Minnesota}

It was January of 1969 when Theodor Adorno called in the police to defend the Institute for Social Research from a student sit-in; at that point the contradictions of the Frankfurt School's Critical Theory project may have been at their rawest. Here, in the midst of what many saw as an international revolutionary moment, one of the very forefathers of the radical students' agenda was to intervene on the side of state power. For the student radicals, Adorno's stubborn position was that of a complacent grumbler, an armchair malcontent unwilling to face the risks of Critical Theory's actualization. But Adorno's contradictory - some would say compromised - position regarding the possibility of real social change requires a second look.

His provocative response to the student movement - just one of many moments of antagonism with the restless energies of the youthful left - is hardly incommensurable with his commitment to using thought to change the way things are. As he would point out in the 1969 essay "Resignation" (included in the recent volume Critical Models: Interventions and Catchwords, edited by Henry Pickford), those who would measure commitment by indexing it to action fall prey to the very conditions they seek to transform. The student radicals, he argued, valorized action over theory, their intolerance of reflective thought served to reproduce the repressive conditions theory was meant to critique in the first place.

Faced with a contradictory totality in which every act is corrupted by the dictates of a ruthless capitalism, the student radicals, Adorno claimed, were acting out of anxiety more than true commitment to social change - their praxis was a substitutive satisfaction born of helplessness in the face of an increasingly totalitarian world. Not unlike the "keep busy" homilies proffered to mournful survivors of a recently deceased friend, their actions were vain 
attempts to avoid confronting the immensity of a plight: as he put it, "one clings to action for the sake of the impossibility of action" (290).

It is a testament to the rigorous consistency of Adorno's materialist dialectical thought that his criticisms of the student left echoed those he had leveled at his nemeses for decades - Adorno's scorn for the self-important "pseudo-activity" of individuals under modern capitalism knew few limits. Yet the impression of Adorno as a surly contrarian, with a frown as severe as his attitude was aloof, has of late been subjected to considerable revision. Burgeoning recent interest in America, fueled by Marxist literary critic Fredric Jameson's tireless championing of Adorno, and buoyed by Robert Hullot-Kentor's stellar retranslation of the masterful Aesthetic Theory, means that the time is right for that reconsideration.

As meditations on the predicament of the modern public intellectual, these texts have their antecedent in the breathtaking Minima Moralia, a collection of aphorisms from the 1950s in which the extremes of Adorno's negative dialectical approach were brought to bear on the most intimate and mundane details of modern life, from marriage and divorce to driving a car. But while the focus in that book was generally the claustrophobic private sphere (where Adorno memorably suggests that the modern subject is inevitably condemned to the "shame of still having air to breathe, in hell"), the later texts compiled here are of a surprisingly public stripe, in many cases based on the radio talks he made with great frequency in the two decades prior to his death,

Whether confronting a particularly vapid TV sitcom or Germany's holocaust legacy, Adorno insisted on a rigorous commitment to a brand of philosophical critique jeopardized by capitalism's subjection of virtually every modern realm to the dictates of standardization and conformity. Subtly threading his way between the twin dangers of apologetic submission to the status quo and arrogant faith in the infallibility of subjective agency, his conclusions are at once grim and utopian. "Whoever puts forward proposals easily makes himself into an accomplice," he argues. "A purist attitude, however, that refrains from intervening, likewise reinforces that from which it timorously recoils" (4). Only in 
thought could critique find a legitimate space from which to counter the overarching social tendencies. To think autonomously, in conditions bent on extirpating autonomous thought, is to resist.

The very insatiability of a thought that seeks to think differently indicates, for Adorono, philosophy's continued relevance. In the book's opening essay, "Why Still Philosophy?," he inveighs against the regnant models of thinking for their betrayal of the critical aspect that has defined philosophy from Xenophanes to Aristotle to Kant, Leibniz, Hegel, and Marx. Torn between what he sees as the one-dimensional rationality of logical positivism and the Heideggerian ontologies that regard conceptual labors as a mere obstacle to the unfolding of Being, "thinking becomes a necessary evil and is broadly discredited" (9). Neutralized by its specialization and disciplinarization, philosophy has become an insider's sport preoccupied with reified method for method's sake, forgetting its social obligations and sacrificing its commitment to freedom.

As in all of Adorno's work, the process of thinking - the machinery whereby reason can occasionally glimpse something like truth is expressed in the form of maddening reversals, improbable paradoxes, and sentences which syntactically lash back on themselves before imploding, leaving behind not stable concepts but only the residual afterimages of concept-creation. Truth is a "constantly evolving constellation" (131) and thought a "nonparticularized pursuit" (6); the intersections between the two only emerge when the thinker gives him or herself over to the object with both respect and critical rigor. Thus does philosophy have to face that which is not identical to it, ceasing "to content itself with cognitions that are predictable and from which nothing more emerges than what had been placed there beforehand" (128).

Such a sentiment might apply just as much to those who wish to hastily judge Adorno as to those immersed in Heldeggmanism, Hegelian identity-thinking, or positivist apology Pickford's collection ably documents an Adorno in which critical cantankerousness is harnessed to a belief in the political and philosophical significance of everyday life. He is at times swashbuckling and irascible, as in "Television as Ideology", where matter-of-fact sarcasm functions as critically as the dialectic it accompanies. But just as 
readily does his rigor take the form of a melancholy determination; "I have exaggerated the somber side...." he admits, in "The Meaning of Working Through the Past", a meditation on the stakes of Holocaust remembrance (the healing aspects of which he suggests to be complicit with a desire to forget).

Not content to sit back and lament philosophy's supposed obsolescence as a tool of social transformation, Adorno.in Critical Models directs his gaze outward, turning away from the ossified confines of philosophical method and toward an open future of improbable possibility. Unlike the students who so pilloried him in the 1960s, Adorno's demand is for a patient, composed and deliberate alertness to the outlines of that future, glimmering into perceptibility on a distant horizon. His refusal to provide quick and dirty satisfaction to the desire for change may appear to activist types as a philosophy content to run in unceasing dialectical circles, like a restless dog biting its own tail. Yet given Adorno's depiction of the stakes of thought in late capitalism, we should perhaps be thankful to his Critical Models for sustaining hope that philosophy can bite anything at all. 